\title{
PROTECTION OF RIGHTS UNDER RUSSIAN CIVIL LAW IN A COMPARATIVE CONTEXT
}

\author{
DENIS KARKHALEV, \\ Bashkir State University \\ (Ufa, Russia)
}

DOI:10.21684/2412-2343-2016-3-1-126-137

The article analyzes the new rules securing the protection of rights introduced in the Russian Civil Code. New enforcement provisions in the Code will contribute to the stability and sustainability of business transactions in the market economy and the observance of contractual discipline. They aim at ensuring the most complete restoration of violated civil rights and restoring the situation that existed before the violation. Positive changes appear in Article 395 of the Code, including penalties prescribing interest payments on unpaid funds for nonperformance of a monetary obligation. The changes to this article have already been tested in practice, as found in a number of interpretations announced in the decisions of higher courts of the judiciary. Yet, an analysis of the Code reveals the absence of any form of penalty in the chapters on the individual types of obligations. Furthermore, a forfeiture occurs only in certain circumstances where it is required due to the nature of the legal relations, as under, for example, transport charters and codes, and laws on the supply of goods for state requirements.

Keywords: protection of civil rights; responsibility in civil law; protection of civil relations.

Recommended citation: Denis Karkhalev, Protection of Rights under Russian Civil Law in a Comparative Context, 3(1) BRICS Law Journal 126-137 (2016).

\section{Introduction}

The remedies for the violation of civil rights are provided for in Article 12 of the Civil Code of the Russian Federation (hereinafter, the Civil Code or CC) and in other federal laws. Article 12 of the Civil Code recognises the general methods by which rights are 
protected and include (among others): recognition of the right; restoration of the situation that existed before the infringement of the right; suppression of the actions infringing the right or creating the threat of its infringement; acknowledgement of the transaction as void and application of the consequences of its invalidity; recovery of damages; self-defense of the right; and compensation for moral damage. Application of the method of protection depends on two factors - the nature of the right protected and the nature of the offence. Participants in business relations may make use of these general methods, and special measures provided for in specific parts of the Civil Code and other federal laws, for violations of their rights.

The protection of rights in the substantive sense of the term is defined as a system of measures of legal influence (measures of protection) that are applied in the event of violation of rights and that are directed at their restoration. The protection of civil rights is characterized by a system of measures provided by law aimed at ensuring the inviolability of rights, restoration of violated rights and suppression of actions infringing the rights.

\section{Protective Civil Relationship}

The protection of civil rights is implemented within a relationship, a particular legal context, that sets down the measures of civil-legal coercion and that is characterized by the possibility of enforcement. The basis of the occurrence of this relationship is improper (i.e. illegal) action. It should be noted that for the obliged party the relationship has an adverse effect. In addition, it is a feature of the content of legal relations that they consist of only the independent subjective right to the protection and security of obligations, thus safeguarding legal relations entered into, and aimed at ensuring the protection (recovery) of subjective civil rights or interests. The relationship is retrospective in nature (it occurs after the violation or threatened violation of law) and the regulation of the corresponding legal relations is carried out on the basis of the protective rules contained in the civil law.

The relationship embodies coercion and enforcement of legal relations that serve the protection of civil rights. Their occurrence depends on the violation of a subjective right; they are based on proprietary standards. The implementation of coercive measures cannot be outside the framework of legal relations, thus the relationship may be called a legal relationship for civil rights.

The object of any enforcement obligations are the actions (behavior) that must commit the offender to the restoration of violated subjective civil rights (or interests).

The subject of the civil law in respect of legal capacity can include both regulatory law (and incur regulatory obligations) and law enforcement. It should highlight the regulatory and enforcement capacity of the injured person (the ability to have the right to protection). Legal capacity starts with the birth of the person (or creation of the legal entity). By virtue of the same legal capacity a person may exercise 
regulatory law (of contract) and demand the protection of civil rights (to exercise the right of defense).

In the framework of ordinary capacity, it is necessary to distinguish two elements: (1) the ability of a person's actions to acquire and exercise regulatory, subjective civil rights and to fulfill regulatory obligations (regulatory capacity); (2) the ability of the injured person by his actions to acquire and exercise civil enforcement of a subjective right (right to protection) and to create enforcement obligations and execute them (protective capability). Full legal capacity begins at the age of eighteen.

The contents of legal relations in civil law is the right of victims to the use of civil coercion (the right to protection) and the obligation of the offender to restore the violated civil right (enforcement responsibility).

The subjective right to protection consists of the following three powers: (1) the ability (competence) to take the actual steps for the protection of the law (on the application of measures of self-defense) or to take independent legal action to restore the right (on the application of measures of operative influence); (2) the ability (competence) to require public authorities to authoritatively restore the violated right (on the application of measures of protection and measures of liability); (3) the ability (competence) to secure the protection of proprietary rights (on the application of coercive measures in a new protective civil relationship). These powers, in my opinion, indicate the independent right to defense.

The subjective enforcement responsibility consists of three elements: (1) the 'responsibility' (the need) to perform a certain action on restoration of the violated right - when implementing measures of protection or measures of responsibility; (2) the 'duty' (the need) to refrain from committing illegal actions in case of breach of contract or beginning of such actions (for the purpose of mitigation) on the part of the injured person - in measures of self-protection or operational impact; (3) the 'responsibility' (the need) to perform a certain action to restore enforcement of the law in the application of sanctions in the new legal relationship arising from the violation of a protective civil relationship.

The enforcement of obligations is reflected in the fact that the offender hands over property to the injured party. This legitimate legal action is a unilateral action (the will). The victim then takes the property from the offender. The reception of the property is also a unilateral action (the will). Performance can be expressed also in the commission of property or non-property unilateral actions (restoration of rights) unrelated to the transfer of property. Thus, the execution of enforcement of commitments represents one or more unilateral actions that result in the restoration of violated civil rights.

The case of nonperformance or improper performance of an obligation (wrongful act) is an independent protective civil relationship, which I propose to call a subprotective relationship. The principal feature of this relationship is that it arises on the basis of the (initial) protective civil relationship. The basis of the subprotective 
relationship is a violation of law enforcement's initial enforcement of the liability expressed in the nonperformance (or improper performance) of an obligation.

The entitlement to protection as an independent subjective right may be violated. If the right to protection is violated, it is obvious, there must arise a new secure relationship, which should exercise a new right to protection (subprotection right) and new subprotection obligation.

Civil rights in business relations are characterized by strict liability as stipulated in Article 401 of the Civil Code. Those engaged in these relations are professional participants in commercial activity, thus they must be circumspect and responsible so as to comply scrupulously with their contractual obligations. According to Article 401, the basis for exemption from liability of persons engaged in commercial activity is where the intervention of unavoidable, extraordinary circumstances make it impossible to carry out the obligation. Thus the basis is cause, not excuse. Here, we are speaking of responsibility on an objective basis.

Hence, the principal feature of commercial activity is that its participants have a heightened responsibility in the event of violation of obligations. The liability of persons engaged in commercial activities is built on the basis of risk - they are responsible, unless they prove that proper discharge of their obligations has been impossible owing to insuperable forces (Art. $401 \mathrm{CC}$ ). If a person is responsible for the breach of an obligation or for injury regardless of fault, that person bears the burden of proving the circumstances which are the basis for exemption from liability.

\section{Damages in Russian, European and Anglo-American Law}

Remedies must be seen in the retrospective, narrow sense of the word, as measures implemented after the breach. The main method of rights protection in business relations is damages. A loss within the meaning of paragraph 2 Article 15 of the Civil Code should be understood as expenses that the person whose right is violated made or must make to restore the violated right, loss or damage to his property (actual damage), as well as lost income he would have received under normal business conditions if his right had not been violated (lost profits).

If the person who has violated a right has received income as a result, the victim has the right to demand compensation along with other losses of missed benefit in an amount not smaller than such income.

The determination of damages, in accordance with paragraph 3 Article 393 of the Civil Code, should be based on the existing prices at the place where the person should have discharged the obligation and on the date of his voluntary performance of that duty, unless the law or the contract provides otherwise.

The new resolution of the Plenum of the Supreme Court of the Russian Federation No. 25 dated June $23,2015^{\prime}$ On application by courts of certain provisions of section 
I of part one of the Civil Code of the Russian Federation' (hereinafter - Decree No. 25) states that the amount of recoverable damages must be established with a reasonable degree of certainty (clause 12).

The application of the analyzed method of protection has well-known difficulties of a procedural nature, since in a market economy to prove the loss may not be easy, especially when it comes to loss of profits. In paragraph 14 Decree No. 25 this feature is highlighted, that the loss of profit is lost income, the calculation of which is approximate and probabilistic in nature. But this fact in itself cannot be grounds for denial of rights.

In practice, there are a number of ways of determining the amount of loss, which include: based on the weighted average of income received in the preceding time period; based on the size of the profit obtained under normal conditions of business activity in the market for a certain product; and based on measures taken by the creditor and made with regard to arrangements in respect of anticipated profits.

Damages as a measure of contractual liability are characterized by the fact that they require four conditions: loss, fault, causation and wrongfulness. The imposition on the offender of these costs characterizes the element of punishment of the offender and shows the orientation of this measure not only to restore legal provisions, but also to influence the penalty.

Under German law, the requirement of monetary damages is a subsidiary sanction to the real requirement of execution of the obligation. The German Civil Code provides that the debtor must restore the position that would have existed but for the circumstances that created a duty to pay damages ( $\$ 249$ BGB), i.e. the debtor's first duty is to performance. If performance has become impossible, the debtor is obliged to make compensation for the damage ( $1 \S 251$ BGB).

In German law, the replacement of specific performance by monetary compensation may occur only in strictly limited circumstances, for example if compliance 'in kind' is impossible, is fraught with disproportionately large burden (para. $2 \S 251 \mathrm{BGB}$ ), or if compliance is associated with intrusion into the sphere of the purely personal relations of the debtor, or forces him into a creative activity.

In Anglo-American law, the basis for legal-political responsibility in the form of damages are the following conditions: availability of losses (harm), wrongful action (inaction), the causal connection between the wrongful conduct and damages and fault. These conditions are required in the case of the occurrence of contractual liability and in the event of tort liability. ${ }^{2}$

The German Law of Torts: A Comparative Treatise 90 (4th Ed., Hart Publishing 2002).

2 Белых В.С. Понятие договорной ответственности по праву Англии и России, 19 Юрист 41-43 (2013) [Belykh V.S. Ponyatie dogovornoy otvetstvennosti po pravy Anglii I Rossii, 19 Yurist 41-43 (2013) [Belykh V.S. Concept of contractual liability law of England and Russia, 19 Lawyer 41-43 (2013)]]. 
American law has not embraced the concept of fault as mental relation of the debtor to his actions and grounded in a finding of guilt based on objective facts. ${ }^{3}$ However, it is allowed and so is no-fault based liability. Causation in Anglo-American law is as follows: compensation shall be recovered only for such losses arising out of a breach of contract, which is the natural and direct consequence of the breach of contract or is within the limits of foresight of both parties at the time of the conclusion of the contract. ${ }^{4}$

In comparison, French legal science does not make a clear distinction between 'wrongfulness' and 'guilt'. The two concepts are merged in the notion of 'faute' ('guilt').

In the Uniform Commercial Code (UCC) of the USA (V.2-715, 2-700), compensation for the related losses is considered, and under which reference is made to those costs incurred by a party with the aim of reducing the amount of loss caused by improper performance or nonperformance of the contract.

Article 2-710 of the UCC refers to the seller's incidental damages, which include any reasonable charges, commissions and costs associated with the suspension of delivery, carriage, storage of goods and care for them following a breach of contract by the buyer, in connection with the return or resale of goods or otherwise resulting from breach of contract.

American contract law acknowledges liquidated damages. ${ }^{6}$ The parties to the agreement may provide for a certain amount, which will be paid by the party at fault to the injured party in case of a specific breach of contract. This is essentially a penalty, which is intended for restoration, that is, compensation for a loss.

A.S. Komarov found that in contrast to continental law Anglo-American law based its approach to the problem of contractual penalties on the recognition of the opportunity to provide them freer expression.

Nominal damages are usually collected in the amount of one dollar and are of an educational character. Punitive damages are carried out only as tort liability in order to censure the person in favor of the state or a charitable organization. ${ }^{7}$

In comparison, continental law has moratoria and compensatory damages. Compensatory damages indemnify for a loss suffered as the result of breach of an

3 Burdick Francis M. The Law of Torts 543-579 (BeardBooks, Washington D.C. 2000) (1905).

4 Treitel G.H. Remedies for Breach of Contract. A Comparative Account 117 (Oxford University Press 1988). McCormick C.T. Handbook on the Law of Damages 135 (St. Paul, Minn West Publishing Co. 1935).

5 Цвайгерт К., Кётц Х. Введение в сравнительное правоведение в сфере частного права. Том 2 [Tsvaigert K., Ketc H. Vvedenie v sravnitelnoe pravovedenie v sfere chastnogo prava. Tom 2 [Zweigert K., Katz H. Introduction to comparative law in the field of private law. Volume 2]] 392 (Moscow 2000).

6 Burrows A. Understanding the Law of Obligations 201-240 (Oxford Hart Publishing 1998).

7 Cane P. The Anatomy of Tort Law (Oxford Hart Publishing 1997); Miller C.J., Lovell P.A. Product Liability (Butterworth, London 1977). 
obligation, they replace the performance, therefore one or the other - damages or performance - may be claimed, but not both. Moratoria damages shall be recovered for delay in performance, even if, for example, the debtor, although late, still fulfills the obligation.

The nature of a causal link between the breach of the obligation and the losses suffered involves remoteness, the most apparent and immediate consequences of nonperformance of a contract being direct, and those not so being indirect.

According to the method of calculation, a loss may be measured in concrete or in abstract terms. Special damages are those actual damages (e.g. loss of profits) that one of the parties suffered as the result of a breach of contract.

French law contains a provision according to which in all cases, regardless of the compulsory execution of obligations, if the creditor suffers losses, he is given the possibility of enforcement (Arts. 1142, 1146-1155, 1611 French Civil Code).

Anglo-American law provides for the possibility of moral damages in the area of tort liability for causing loss. Contractual liability excludes the use of this protection method.

In the Russian Civil Code there are new rules for applying sanctions to be analyzed in other spheres of social relations: damage exists when illegal refusal occurs in state registration of rights to property; damage to a legal person, an individual or collegial body of an organization; damage upon termination of a contract and compensation for material losses in connection with the execution, modification or termination liability, but not involving breach by the debtor (for example, loss caused by the impossibility of performance of obligations against the creditor claims from third parties).

Deserving of support is the inclusion in the law of rules in respect of damages in case of early termination of a contract. In the case where the nonperformance or improper performance by the debtor of the contract led to its early termination and in lieu of it the creditor entered into another transaction (replacement transaction), the creditor is entitled to demand from the debtor compensation of losses in the form of the difference between the price specified in the terminated contract and the price of comparable goods, works or services under the terms of the replacement transaction.

The same can be said about sanctions such as compensation for moral harm. The size of moral harm is difficult to prove; nevertheless, this sanction is often applied in court practice where there is a violation of the moral rights of persons engaged in business activities (for example, the right to reputation).

\section{Penalties in Russia, Germany and France}

In judicial practice the most frequently used means of protecting the rights of participants in business relations is the recovery of damages and interest under Article 395 of the Civil Code. According to Article 333, the size of the penalty may be reduced. In the Decree of the Supreme Arbitrazh Court Plenum No. 81 of 22 December 
2011 'On some issues of applying Article 333 of the Civil Code of the Russian Federation', in claim 1 of which the lower court penalty is associated only with the request of the defendant. In addition, paragraph 2 of the regulation provides that a reduction of the penalty is possible in the provision whereby the defendant offers evidence of the obvious disproportionality of the penalty with respect to the consequences of the infringement of the obligation (lower potential losses, lower penalties).

In judicial practice, questions are raised concerning the possibility of simultaneous implementation of recovery of damages and interest under Article 395 of the Civil Code. Court practice testifies to the impossibility of application of the two sanctions. It seems that the court has no right in this situation to deny the possibility (the right to defense) of recovery of interest or penalty for the following reasons: in such situations a new commitment and relationship arise in the payment of interest based on independent legal facts, and in each of these specific obligations a measure of responsibility appertains.

Both relations have in their content a subjective right to liquidated damages and the entitlement to interest, which must be implemented. Reducing the size of the penalty or interest and, especially, depriving parties of the possibility to apply one of these should be considered a restriction of legal capacity. No one has the right to deprive a creditor of a protective relationship with respect to his subjective right of defense.

If through penalty obligations the creditor is entitled to liquidated damages and is entitled to interest on the obligation to implement the sanctions of Article 395 of the Civil Code, the court shall apply both measures of coercion and is not entitled to reduce their size. Otherwise, the person loses the ability to protect his infringed rights in full and the purpose of a protective relationship will not be achieved. If the question arises as to the excessive amount of penalties, the way out of the situation is to void the transaction in part.

Penalty can be used as a method of protection. According to $\S 339 \mathrm{BGB}$, penalty is the amount of money that the debtor is obligated to pay in case of nonperformance or improper performance of obligations or delay of execution. If the creditor is entitled to damages, which emerged in the wake of the failure to discharge the obligation, then the minimum damages may be paid in the form of liquidated damages ( $\$ 340 \mathrm{BGB}$ ).

The changes made to the Russian Federation Civil Code enshrine the rule on the reduction of the penalty only on application by the debtor. In addition, in the Civil Code special rules are proposed concerning contractual penalty, the reduction of which (if it shall be payable by the person carrying out the business activity) is allowed in exceptional cases where it is proved that the amount involved in the recovery of damages under the contract may result in the creditor receiving unjustified benefits. This proposal should be supported. The drafters of the changes to the Civil Code derive this proposal from the principle of freedom of contract, thus most appropriate only in business relations. 
Contractual liability can be accepted for the payment of interest under Article 395 of the Civil Code. The offender carries an additional penalty in the amount established by this article. The basis of the application of this measure of responsibility is an offence that includes two conditions: the use of other people's money and guilt.

The basis of the application of this sanction is not the use, but the illegal possession of other people's money. A condition of illegality is necessary for the application of this measure of liability, with the fact of ownership of other people's money being sufficient grounds. For the recovery of interest it is not required of the courts to discover whether a profit has resulted through the use of other people's money.

Thus, one of the conditions for the application of these penalties is the failure to perform or improper performance of monetary obligations. The creditor may demand simultaneous payment from the debtor of interest and penalties, if such possibility is provided by law or contract. In the case where the obligation did not arise through business activities and the contract has not provided otherwise, the debtor shall be liable only if found guilty.

Therefore, the collection of interest per annum is an independent measure of responsibility, which is effected in a special protective relationship for the implementation of Article 395 of the Civil Code. The independence of measures of responsibility to a large extent determines the independence of the relations in which it is implemented.

An analysis of the Civil Code of the Russian Federation shows that the chapters on individual types of obligations do not contain any penalties. A forfeiture occurs only in certain circumstances where it is required due to the nature of the legal relations (as under, for example, transport charters and codes, and laws on the supply of goods for state requirements, relations with consumers, etc.).

Thus, the legislator has reduced the number of legitimate penalties and provided an opportunity for the parties, in the manner of individual legal regulation, to use this method of protection of civil rights, and to use it in any violation of any monetary obligations (both regulatory and protective relationships).

An analysis of judicial practice shows that the enforcement authorities admit the possibility of changing (reducing) the amount of interest. We are talking here about the joint Resolution of Plenums of the Supreme Court of the Russian Federation and the Supreme Arbitration Court of the Russian Federation No. 13/14 of 8 December 1998, 'On practice of application of provisions of the Civil Code of the Russian Federation regarding interest for using another's money resources', in which the courts allow lowering the rate of interest on the grounds provided for in Article 333 of the Civil Code.

In the case of non-fulfillment of monetary obligations for payment of interest, the (sub)protection of a new relationship arises for the payment of interest on the initial amount of interest (this is an ordinary money debt). In this case there is no application of one sanction with another sanction (interest on interest). 
Positive changes appear in Article 395 of the Code, including penalties prescribing interest payments on unpaid funds for nonperformance of a monetary obligation. The changes to this article have already been tested in practice, as found in a number of interpretations announced in the decisions of higher courts of the judiciary. Statutory rules referred to above about the impossibility of the simultaneous application of the penalty and the interest, and interest on interest (compound interest) are known to some modern developed legal orders, in particular, German civil law.

However, the recovery of compound interest is not allowed in cases where such a requirement exists within a protective relationship. In the same case, when the annual interest for the breach of an obligation is exacted, and the court decision entered into legal force, the further non-payment of interest charged is a new legal fact - the failure of enforcement of the obligation to pay interest.

In this situation, as noted, there is a new subprotection obligation under which recovery of new interest on the amount unpaid of the charged interest on the first obligation is permitted. Arbitral practice on this issue shows a uniform approach.

\section{Restitution, the protection of ownership and property}

The changes to the Civil Code ${ }^{8}$ allow the application of consequences with regard to invalid transactions (restitution). Thus the court is entitled to apply the consequences of invalidity of a voided transaction on its own initiative in cases where this is necessary in order to protect public interests, and in other cases provided for by law.

In addition, in respect of a voided transaction, claim invalidation is allowed, and without the use of restitution, if the person instituting such a requirement has a protected interest in the recognition of the voided transaction. This rule is currently used in practice.

The amendment to the law is acceptable. Moreover, the requirement for the application of the consequences of the invalidity of a voided transaction may be filed by the party to the transaction, and in cases stipulated by law also other persons. This proposal also deserves support, as the commission of a voided transaction may lead to infringement of interests of third parties.

In the drafting of the Civil Code much attention was paid to ownership and the protection of ownership (these standards are currently not yet taken): for example, according to Article 215, the protection of ownership effected by returning the goods to the possession of the person who lost them. The right to protection of possession applies to any owner, of both legal and illegal goods - regardless of whether the owner is entitled to possession.

8 Protection of property rights has also undergone some changes. Article $226 \mathrm{CC}$ lists the methods of property rights protection. 
The right to protection of possession of an owner of illegal goods seems a controversial provision. In this case, the right to protection of ownership will be the person who seized the property. In my view, this issue should be considered a bona fide possession, that is, protection should be given to a lawful and bona fide possession. But to protect illegal possession should be denied. This problem is especially acute in terms of the wave of hostile business takeovers that have swept through Russia in recent times.

The request by the owner for the protection of ownership is subject to the satisfaction of the court that it has been established that the property (i.e. the object or thing) at issue was out of his possession as a result of theft, arbitrariness or otherwise against the will of the owner (Art. 216 CC).

With regard to recovery following the new rules, the owner is not entitled to claim the property from the possession of a person having a limited proprietary right, including right of ownership, unless otherwise established by the Civil Code.

A person having a limited proprietary right, including right of possession, is entitled to reclaim the property from unlawful possession on the same grounds and by the same rules as the owner (for example, an agent may reclaim the property, which he is assigned on a limited proprietary right, from an illegal owner).

The right to a negatory suit is also provided to the owner or person having a limited proprietary right. What is novel is the rule that the owner of the property is also entitled to file negatory claims against persons with limited real rights in the property, if the latter, exercising his rights, goes beyond them. And, finally, a person having a limited proprietary right shall be entitled to file a negatory claim against the owner or against the person having a limited right in rem, if the owner or such person violates a protected property right.

In order to protect the disputed right, an action in rem may be brought by the requirement of recognition of property rights. The defendant in the lawsuit on the recognition of property rights is the person whose rights may be affected by the proprietary right of the plaintiff.

A separate article is planned that contains the protective rules in respect of the application of this method of protection of proprietary rights as the liberation of property from seizure. The claim for the release of property from seizure is filed against the person for whom it was seized, and the debtor or another person on demand, from whom it was seized.

\section{Conclusion}

New enforcement provisions in the Civil Code of the Russian Federation will contribute to the stability and sustainability of business transactions in the market economy and the observance of contractual discipline. They aim at ensuring the most complete restoration of violated civil rights and restoring the situation that existed before the violation. 


\section{References}

Burdick Francis M. The Law of Torts 543-579 (BeardBooks, Washington D.C. 2000) (1905).

Burrows A. Understanding the Law of Obligations 201-240 (Oxford Hart Publishing 1998).

Cane P. The Anatomy of Tort Law (Oxford Hart Publishing 1997);

McCormick C.T. Handbook on the Law of Damages 135 (St. Paul, Minn West Publishing Co. 1935).

Miller C.J., Lovell P.A. Product Liability (Butterworth, London 1977).

Sir Basil Markesinis, QC \& Hannis Unberath, The German Law of Torts: A Comparative Treatise (4th Ed., Hart Publishing 2002).

Treitel G.H. Remedies for Breach of Contract. A Comparative Account (Oxford University Press 1988).

Хохлов В.А. Ответственность за пользование чужими денежными средствами, 8 Хозяйство и право (1996) [Hohlov V.A. Otvetstvennost'za pol'zovanie chuzhimi denezhnymi sredstvami, 8 Hozjajstvo i pravo (1996) [Khokhlov V.A. Responsibility for the use of borrowed cash, 8 Economy and law (1996)].

Цвайгерт К., Кётц Х. Введение в сравнительное правоведение в сфере частного права. Том 2 [Tsvaigert K., Ketc H. Vvedenie $v$ sravnitelnoe pravovedenie $v$ sfere chastnogo prava. Tom 2 [Zweigert K., Katz H. Introduction to comparative law in the field of private law. Volume 2]] (Moscow 2000).

\section{Information about the author}

Karkhalev Denis (Ufa, Russia) - Professor of Civil Law, Bashkir State University (Krasin Street, 15-69, 450076, Russia, Bashkortostan, Ufa; e-mail: dnk001rb@yandex.ru). 